\title{
Перспективы открытия новых крупных месторождений стратегических металлов в Арктической зоне России
}

\author{
Волков А.В., Галямов А.Л., Лобанов К.В. \\ Институт геологии рудных месторождений, петрографии, минералогии и геохимии РАН, Москва, \\ Volkov@igem.ru
}

Аннотация. В статье рассмотрены результаты изучения методами ГИС-анализа соотношения металлогении с геодинамическими обстановками крупных месторождений стратегических металлов в Арктической зоне России Федерации (АЗР). Выявлено сходство геодинамических обстановок формирования невадийских и сакынджинских месторождений золота Карлинского типа (МЗКТ), что подтверждает высокие перспективы открытия крупных месторождений в этом арктическом районе Якутии. Новые рудные районы с МЗКТ прогнозируются на всем протяжении Черско-Полоусненского покровно-складчатого пояса (Колымской петли). Приведенные материалы показывают высокие перспективы открытия на Северо-Востоке России новой металлогенической провинции МЗКТ.

Ключевые слова: Арктическая зона, крупные месторождения, стратегические металлы, Карлинский тип, прогноз.

\section{Prospects for discovery of new large strategic metals deposits in the Arctic zone of Russia}

\author{
Volkov A.V., Galyamov A.L., Lobanov K.V. \\ Institute of Geology of Ore Deposits, Petrography, Mineralogy and Geochemistry, RAS, Moscow, \\ Volkov@igem.ru
}

\begin{abstract}
The article considers the results of studying the correlation of metallogeny with geodynamic setting of large deposits of strategic metals in the Arctic zone of the Russian Federation (AZRF) by GIS-analysis methods. The similarity of geodynamic conditions of formation of Nevadaand the Sakyndzaarea Carlin type gold deposits (CTGD) is revealed, and confirms high prospects of opening the CTGD in this Arctic region of Yakutia. New ore districts with CTGD predicted throughout Chersko-Poluosninsky fold-thrust belts (Kolyma loop). The presented materials show high prospects for the discovery of a new metallogenic province of CTGD in the North-East, of Russia.

Keywords: Arctic zone, large deposits, strategic metals, Carlin type, forecast.
\end{abstract}

\section{Введение}

Арктическая зона России (АЗР) полукольцом охватывает окраину Евразийского континента и многочисленные острова вокруг Северного Ледовитого океана (рис. 1). Недра АЗР богаты не только стратегическими высокотехнологичными металлами, но и другими ценными полезными ископаемыми. Рассмотрены результаты изучения методами ГИС-анализа соотношения металлогении с геодинамическими обстановками крупных месторождений стратегических металлов в Арктической зоне России Федерации (АЗР).

В качестве примера оценки перспектив рудоносности приведены результаты сравнительного металлогенического анализа геодинамических обстановок формирования месторождений золота Карлинского типа (МЗКТ) на основе современных геофизических моделей литосферы Верхоянской, Невадийской и Южнокитайской металлогенических провинций.

\section{Геодинамические обстановки рудообразования}

По данным пространственного ГИС анализа БД, подавляющее большинство рудных месторождений АЗР размещается в терригенных и вулканогенных комплексах, гранитоидах и метаморфических комплексах древнего основания. Месторождения благородных металлов, меди, свинца и цинка залегают преимущественно в терригенных и вулканогенных комплексах (в т.ч. радиоактивные руды), а также в гранитоидах. Для проведения ГИС-анализа применялись известные методические приемы, заложенные в аналитический аппарат ARCMAP, MAPINFO и других картографиче- 


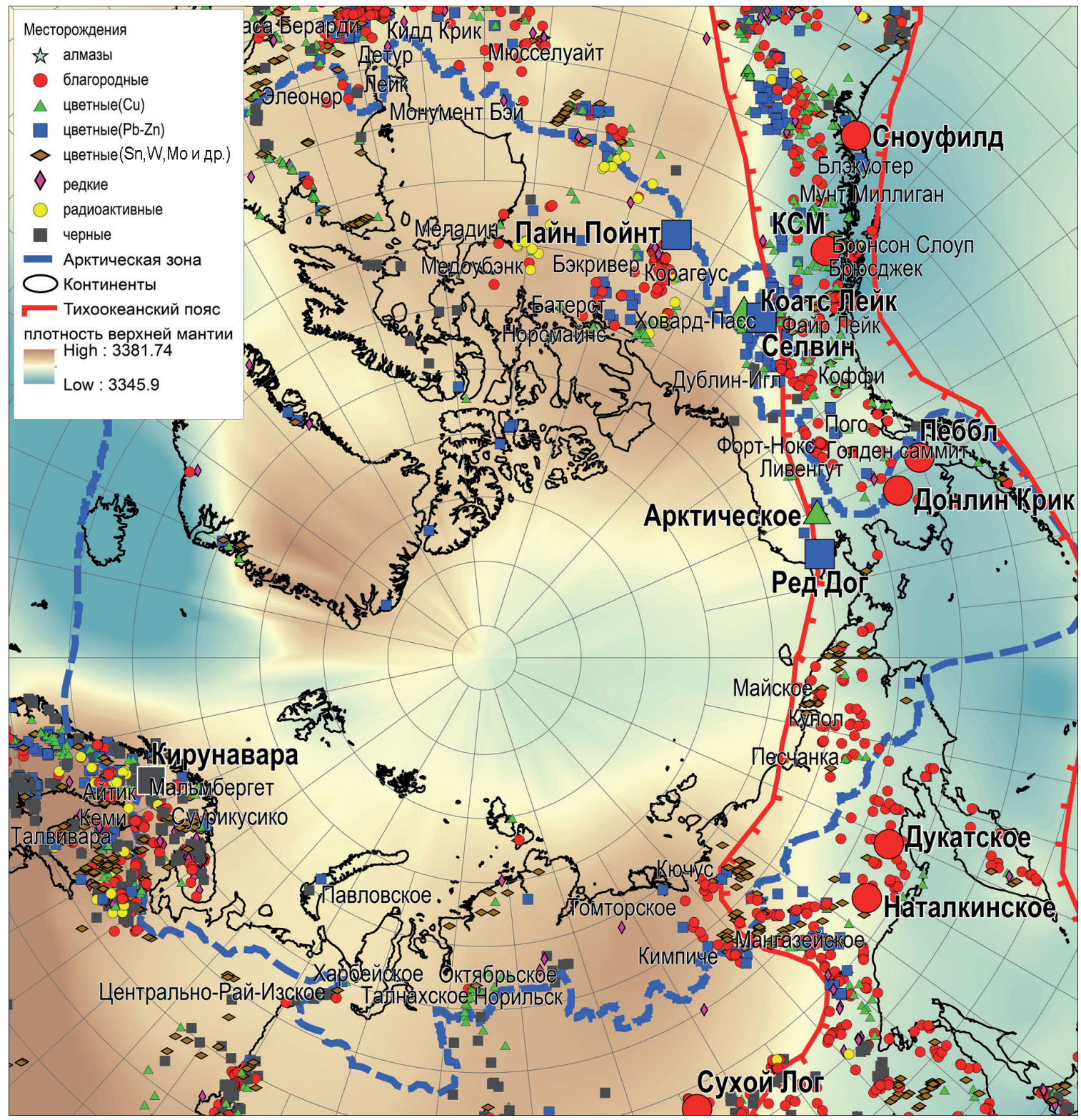

Рис. 1. Схематическая карта плотности верхней мантии (Bouman et al., 2015) и распределения основных месторождений и перспективных рудопроявлений стратегических металлов в Арктике.

Fig. 1. A schematic map of the density of the upper mantle (Baumann et al., 2015) and distribution of the main deposits and prospective ore occurrences of strategic metals in the Arctic.

ских математико-аналитических систем. Наиболее эффективными показали себя устоявшиеся методы выявления и оценки пространственных связей (растровой алгебры, нечеткой логики, вероятностного анализа и др.).

Металлогения других цветных металлов (олово, вольфрам, молибден и др.) проявлены преимущественно в гранитоидных интрузивах и их обрамлении, сложенном терригенными комплексами. Руды редких металлов и редкоземельных элементов связаны с щелочными и субщелочными интрузивами в древнем фундаменте. Месторождения черных металлов (железо, титан, хром и др.) тесно ассоциируют с базитами и ультрабазитами, а также с формацией железистых кварцитов в выступах древнего основания. В таблице представлено соотношение минералообразующих систем и геодинамических обстановок в АЗР.

В континентально части АЗР наиболее рудоносными и перспективными на выявление новых объектов стратегических металлов являются три геодинамические обстановки в формационных комплексах которых залегает подавляющее большинство (более 70 \%) месторождений (табл. 1): 
1. Выступы древнего основания, включающие блоки архейских кратонов, древние рифтогенные структуры и области орогенной активизации; 2. Ареалы формаций пассивной континентальной окраины, включая современные им рифтогенные структуры; 3. Комплексы активной окраины, включая островодужные вулканические постройки.

В выступах древнего основания, в пределах Балтийского щита и др., размещается около 30 \% месторождений стратегических металлов. Важное место по числу месторождений (30 \%) в России занимают ареалы пассивной континентальной окраины и зоны континентальных и субконтинентальных рифтогенных прогибов. Здесь преобладают месторождения цветных и благородных металлов, расположенные в складчатом обрамлении Сибирской платформы и Среднем Урале. В обстановках активной окраины, включая островные дуги (около 30 \%), наибольшим распространением в зоне влияния Охотско-Чукотского вулкано-плутонического пояса и в островодужных комплексах Камчатки пользуются объекты благородных, цветных и черных металлов, причем в областях конвергенции пассивного режима восточной окраины Сибирского кратона число месторождений указанных типов несколько больше.

Литосфера АЗР, сформированная в ходе нескольких суперконтинентальных циклов, включает древние щиты (Балтийский, Анабарский), перекрывающие их позднедокембрийский и палеозойский платформенные чехлы, складчатые орогенные пояса (Каледонский, Уральский, Таймырский, Тиманский, Верхояно-Чукотский), разделяющие древние платформы (Восточно-Европейскую, Сибирскую и Северо-Американскую), внутриплитные магматические провинции различных эпох от раннего докембрия до кайнозоя и мезозойские вулканогенные пояса (Святоносно-Олойский, Уяндино-Ясаченский и Охотско-Чукотский).

Геодинамические обстановки развития литосферы на западном и восточном флангах российской Арктики заметно отличались друг от друга. По представлениям Л.М.Парфенова (1984), на северо-востоке России пассивные и активные континентальные окраины с островными дугами существовали начиная с рифея. Позднее в этом регионе Евразии происходила длительная кратонизация, которая завершилась лишь в позднем мезозое. Следует отметить, что эта группа геодинамических обстановок принадлежит Тихоокеанскому рудному поясу (см. рис. 1).Соотношение минералообразующих системи геодинамических обстановок показано в табл. 1.

К геодинамическим обстановкам западной части АЗРФв докембрийских щитах и на их периферии относятся:

1. Континентальные рифты, крупные изверженные провинции. Именно в этой обстановке формируются сульфидный $\mathrm{Ni}-\mathrm{Cu}, \mathrm{Ni}-\mathrm{Cu}-\mathrm{Co}$ и $\mathrm{Ni}-\mathrm{Cu}-\mathrm{PGE}$, хромититовый, оксидный $\mathrm{Fe}-\mathrm{Ti}-\mathrm{V}$ с магнетитом минеральные типы месторождений Норильского рудного района и Карело-Кольского региона.

2. С обстановкой внутриплитного щелочно-гранитоидного магматизма связаны кимберлитовый и лампроитовый алмазоносный, апатит-магнетит-РЗЭ-редкометалльный карбонатитовый, апатит-нефелиновый РЗЭ-редкометалльный в расслоенных щелочных интрузиях минеральные типы крупных месторождений Балтийского и Анабарского докембрийских щитов.

3. В обстановках пассивной континентальной окраины, осадочных бассейнов и рифтогенных прогибах образовались стратиформные месторождения MVT- и SEDEX-типов, Cu-Co-Ag-песчаники и сланцы (Пай-Хой, Новая Земля, Полярный Урал), U-типа несогласия (Анабарский щит).

4. В зеленокаменных поясах Балтийского и Анабарского щитов формировались месторождения золота орогенного типа, Ni-Cu-PGE и колчеданно-полиметаллические, золотоносные конгломераты, редкометалльные пегматиты и железистые кварциты.

Геодинамические обстановки Тихоокеанского рудного пояса представлены:

1. Островодужными террейнамии окраинно-континентальными вулканическими поясами, зонами постоорогенной тектоно-магматической активизации. В этих обстановках формируют-

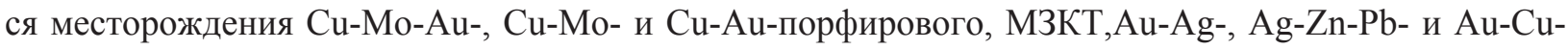
эпитермального, $\mathrm{Cu}-\mathrm{Au}-$ и $\mathrm{Zn}-\mathrm{Pb}-\mathrm{Ag}$ скарнового типов Чукотки. 
Таблица 1. Соотношение минералообразующих системи геодинамических обстановок. Table 1. Correlation of mineral-forming systems and geodynamic settings.

\begin{tabular}{|c|c|c|}
\hline Геодинамическая обстановка & Минералообразующая система & Минеральные типы месторождений \\
\hline $\begin{array}{l}\text { Зоны щелочного гранитоидного } \\
\text { магматизма в кратонах }\end{array}$ & Щелочно-гранитодная & $\begin{array}{l}\text { Кимберлитовый алмазоносный, } \\
\text { апатит-нефелиновый P3Э-редкоме- } \\
\text { талльный в расслоенных щелочных } \\
\text { интрузиях (REE-P-U) медно-никеле- } \\
\text { вый платиноносный (Ni-Cu-PGE). }\end{array}$ \\
\hline $\begin{array}{l}\text { Континентальные рифты, круп- } \\
\text { ные изверженные провинции } \\
\text { (LIP), срединно-океанические } \\
\text { хребты }\end{array}$ & $\begin{array}{l}\text { Мафит-ультрамафитовая орто- } \\
\text { магматическая }\end{array}$ & $\begin{array}{l}\text { Сульфидный Ni-Cu, Ni-Cu-Co и Ni- } \\
\text { Cu-PGE, хромититовый, оксидный } \\
\text { Fe-Ti-V с магнетитом }\end{array}$ \\
\hline $\begin{array}{l}\text { Активные окраины, аккреци- } \\
\text { онно-коллизионные террейны }\end{array}$ & Порфировая эпитермальная & $\begin{array}{l}\text { порфировый } \mathrm{Cu}-\mathrm{Au}-\mathrm{Mo} \text {, эпитермаль- } \\
\text { ный } \mathrm{Au}-\mathrm{Ag}, \mathrm{Ag}-\mathrm{Zn}-\mathrm{Pb} \text { и } \mathrm{Au}-\mathrm{Cu}, \text { скар- } \\
\text { новый } \mathrm{Cu}-\mathrm{Au} \text { и } \mathrm{Zn}-\mathrm{Pb}-\mathrm{Ag} \text {, }\end{array}$ \\
\hline $\begin{array}{l}\text { Срединно-океанических хребтов } \\
\text { (СОХ), островодужные структу- } \\
\text { ры, рифтогенные прогибы }\end{array}$ & Подводная вулканогенная & $\begin{array}{l}\text { медно-колчеданный (VHMS), } \\
\text { колчеданно-полиметаллический }\end{array}$ \\
\hline $\begin{array}{l}\text { Пассивных континентальных } \\
\text { окраин, включая рифтогенные } \\
\text { прогибы }\end{array}$ & Осадочно-гидротермальная & Стратиформные MVT- и SEDEX-типы \\
\hline $\begin{array}{l}\text { Области орогенного и посторо- } \\
\text { генного магматизма }\end{array}$ & Гранитоидная & $\begin{array}{l}\text { Золото-кварцевый жильный, золото- } \\
\text { сульфидно-кварцевый, МЗКТ, грейзе- } \\
\text { новый Sn-W-F, пегматитовый Ta-Nb- } \\
\text { Li-Be, порфировый Mo }\end{array}$ \\
\hline Орогенеза & Орогенная & $\begin{array}{l}\text { гидротермальный жильный } \mathrm{Au}, \mathrm{Cu} \text {, } \\
\mathrm{Zn}-\mathrm{Pb}-\mathrm{Ag} \text { с сульфидами }\end{array}$ \\
\hline $\begin{array}{l}\text { Области анорогенного гранито- } \\
\text { идного магматизма }\end{array}$ & Железо-оксидная & $\begin{array}{l}\text { Железо-оксидный медно- } \\
\text { золоторудный (IOCG) }\end{array}$ \\
\hline
\end{tabular}

2. Срединно-океаническими хребтами (COX), островодужными поясами, рифтогенными прогибами с медно-колчеданными (VHMS) и колчеданно-полиметаллическими типами месторождений (Полярный Урал, Майницкий террейн, Северная Корякия).

3. Коллизионно-аккреционные террейны пассивной континентальной окраины, области орогенного и посторогенного магматизма. С этой обстановкой связаны: золото-кварцевый жильный, золото-сульфидно-кварцевый штокверковый, золото-сульфидный вкрапленный, грейзеновый Sn$\mathrm{W}-\mathrm{F}, \mathrm{Sn}$-сульфидный, Ta-Nb-Li-Be пегматитовый, Мо-порфировый, Mo-U гидротермальный, Au связанные с интрузивами гранитоидов, $\mathrm{Zn}-\mathrm{Pb}-\mathrm{Ag}$-жильныйтипы месторождений. В коллизионных швах локализуются амагматичные $\mathrm{Hg}$, МЗКТ, $\mathrm{Au}-\mathrm{Sb}-\mathrm{Hg}$ и $\mathrm{Au}-\mathrm{Sb}$ месторождения (северо-восток Якутии, западная и центральная Чукотка).

4. Задуговые бассейны, области анорогенного гранитоидного магматизма, вмещающие крупные железо-оксидно-медно-золоторудные месторождения (IOCG-типа). Прогнозируются насеверовостоке Якутии и Чукотке.

\section{Геофизическая модель литосферы и МЗКТ}

В качестве примера оценки перспектив рудоносности рассмотрим результатысравнительного металлогенического анализа геодинамических обстановок формирования месторождений золота Карлинского типа (МЗКТ) на основе современных геофизических моделей литосферы Верхоянской, Невадийской и Южнокитайской металлогенических провинций.

МЗКТ представляет собой крупные метасоматические тела джаспероидов в карбонатных вмещающих породах, которые содержат субмикроскопическое тонкодисперсное золото во вкрапленном пирите или марказите. Месторождения встречаются в рудных узлах (кластерах), сосредоточенных вдоль достаточно протяженных трендов (разломов). Для МЗКТ характерны сходные гидротермальные изменения и рудные парагенезисы: растворение и окремнение карбоната, сульфидизация 
железа во вмещающих породах, формирование Аu содержащего мышьяковистого пирита и марказита происходило в закрытой системе, а позднее, в открытой системе - отложение аурипигмента, реальгара и антимонита, минералов таллия (Волков, Сидоров, 2016).

За пределами Невады, вкрапленные месторождения Аu в осадочных породах сосредоточены на юге Китая (рис. 2) и встречаются локально по всему миру, в частности, на Балканах. Хотя тектонические обстановки формирования этих месторождений отличаются от Невадийских, вкрапленные месторождения Аu в осадочных породах Западно-Циньлинского пояса и области Диан-ЦяньГуй южного Китая и месторождение Алшар в Козуфском районе Македонии наиболее близки к МЗКТ (Волков, Сидоров, 2016).В последнем отчете геологической службы США Карлинский и Китайский подтипы месторождений объединяются в рамках одной популяции (класса) - месторождений золота в осадочных толщах («sediment-hosted gold deposits»), которые характеризуются вкрапленным микронным невидимым золотом (Bergeretal, 2014).

По многим объектам в мире высказываются противоположные версии относительно того, Карлинского типа это месторождение или только похоже на него или оно относится к другому типу месторождений золота в осадочных породах. Так, к Карлинскому типу в России отнесены некото-

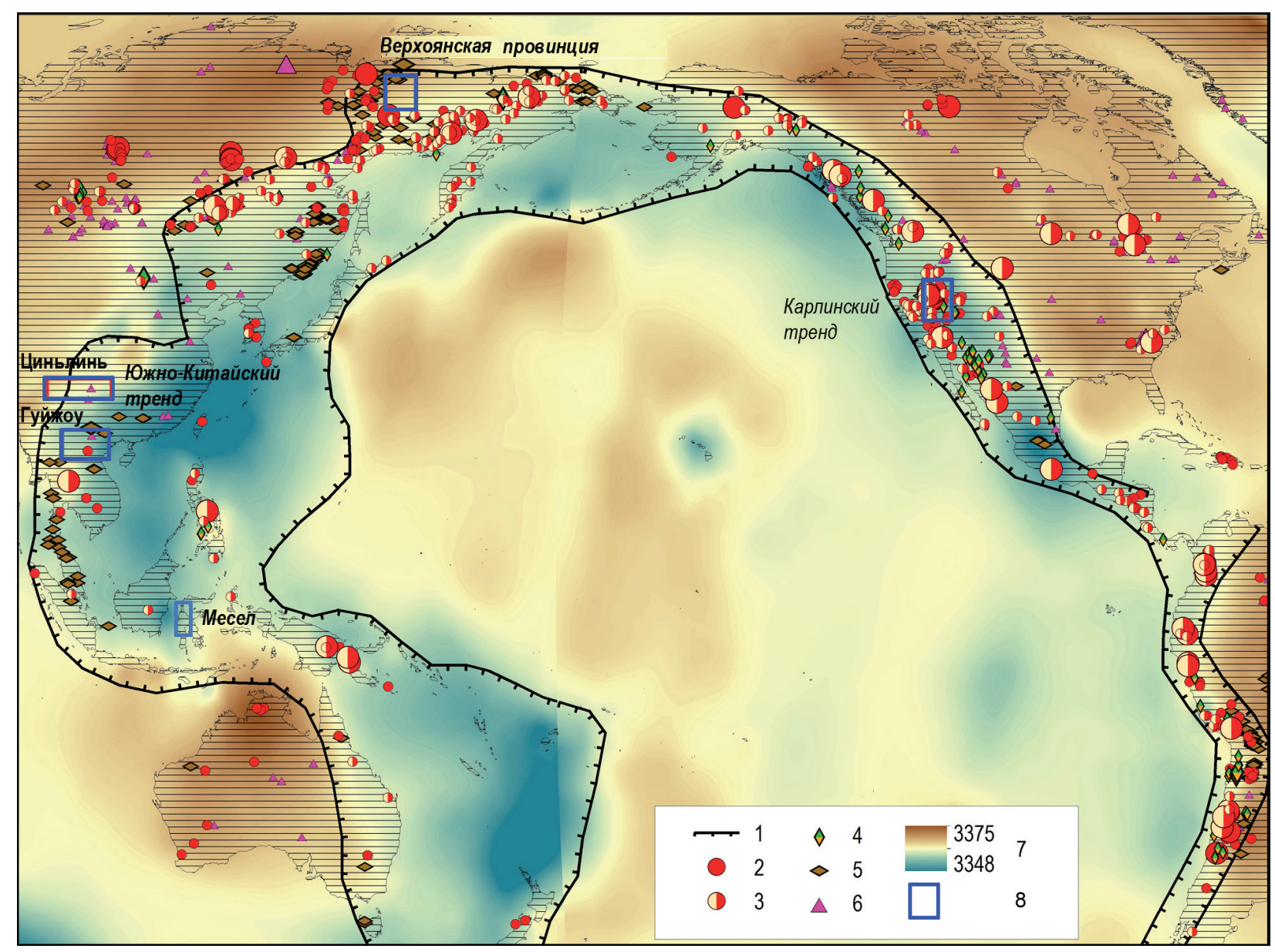

Рис. 2. Пространственное размещение районов МЗКТ в Тихоокеанском рудном поясе, по данным ГИС-анализа на карте плотности верхней мантии, проект CRUST 2.0 (Laskeetal, 2000).

1- границы Тихоокеанского рудного пояса; 2-6 - месторождения: 2 - Au в терригенных толщах, 3 - Au-Ag эпитермальные, 4 - Cu-Mo-Au-порфировые, 5 - Sn, 6 - редкометалльные; 7 - плотность верхней мантии $\left(г / \mathrm{cm}^{3}\right) ; 8$ - рудные районы с МЗКТ.

Fig. 2. The spatial distribution of the Carlin type gold deposits (CTGD) areas in the Pacific ore belt, according to the GIS analysis on the map of the upper mantle density, Project CRUST 2.0 (Laskeetal, 2000):

1 - borders of the Pacific ore belt; 2-6 - ore deposits: 2 - Au in terrigenous strata, 3 - Au-Ag epithermal, 4 - Cu-Mo-Auporphyry, 5 - Sn, 6 - rare metals; 7 - the upper mantle density $\left(\mathrm{g} / \mathrm{cm}^{3}\right) ; 8$ - CTGD ore areas. 
рые месторождения Урала (Воронцовское и Светлинское), Верхнего Приамурья (Чагоянский рудный узел), Южной Якутии (Тас-Юрях) (Поспелов и др., 2002). Сходство перечисленных месторождений с месторождением Карлин обосновывалось преимущественно на минералого-геохимических характеристиках руд.

Детальные структурно-формационные, стратиграфические, литологические и минералогогеохимические исследования в 1996-1998 гг. на Селенняхском хребте (см. рис. 2) показали, что группа золоторудных проявлений Сакынджинского рудного района (Арбат, Гал-Хая и др.) сформировалась в такой же геодинамической обстановке, что и группа месторождений Карлинского тренда (Поспелов и др., 2002).

Для объяснения закономерностей размещения и условий формирования МЗКТ в докладе проанализированы современные геофизические исследования литосферы: поверхности Мохо, плотности и термального режима верхней мантии (Bassinetal, 2000; Boumanetal, 2015; Cammarano, Guerri, 2017; Sampietroetal, 2013). Новая модель GEMMA основана на базе данных о толщине земной коры по результатам сейсмических исследованийунаследована из модели CRUST2.0 (Laskeetal, 2000). Типы коры, определялись в зависимости от возраста фундамента или тектонических условий (Boumanetal, 2015) и для каждой ячейки сети даны глубина границы Мохо, скорость сжатия и скорость сдвига, а также плотность дана для 8 слоев: воды, льда, трехслойного осадочного чехла и верхней, средней и нижней кристаллической коры. Данные осадочных слоев, в основном, соответствуют модели (Boumanetal, 2015).

Результатам сравнительного анализа геодинамических обстановок формирования МЗКТ в штате Невада, Южном Китае и Северо-Востоке России. Региональные тектонические обстановки формирования МЗК приведены в таблице 2. Отметим, что вмещающие МЗКТ породы всех трех регионов в дорудный этап были деформированы, с образованием рудоконтро-лирующих структур, а рудные районы включают также осадочно-эксгаляционные, полиметаллические связанные с интрузиями, и свинцово-цинковые стратиформные месторождения миссиссипского типа. Вместе с тем, южно-китайские месторождения размещены в более кремнистых породах, тогда как руды в Неваде и Верхоянье - в более известковистых породах.

Таблица 2. Сравнительная характеристика геодинамических обстановок формирования МЗКТ США, России и КНР.

Table 2. Comparative characteristics of geodynamic conditions of the Carlin type gold deposits formation in the USA, Russia, and China.

\begin{tabular}{|c|c|c|c|c|}
\hline \multirow[b]{2}{*}{ Параметры } & \multirow{2}{*}{$\begin{array}{r}\text { США } \\
\text { Невада }\end{array}$} & \multirow{2}{*}{\begin{tabular}{l}
\multicolumn{1}{c}{ Россия } \\
Верхояно- \\
Колымская область
\end{tabular}} & \multicolumn{2}{|c|}{ Южный Китай } \\
\hline & & & Провинция Циньлин & Провинция Гуйчжоу \\
\hline Возраст & Третичный & Верхнемезозойский & Юрско-меловой? & Меловой? \\
\hline $\begin{array}{l}\text { Геодинамическая } \\
\text { обстановка }\end{array}$ & $\begin{array}{l}\text { Континенталь- } \\
\text { ная магматическая } \\
\text { дуга, наложенное } \\
\text { растяжение }\end{array}$ & $\begin{array}{l}\text { Коллизионная } \\
\text { магматическая дуга, } \\
\text { посторогенное под- } \\
\text { нятие и растяжение }\end{array}$ & $\begin{array}{l}\text { Коллизионная } \\
\text { магматическая дуга, } \\
\text { посторогенное под- } \\
\text { нятие и растяжение }\end{array}$ & $\begin{array}{l}\text { Вне пределов } \\
\text { магматической дуги. } \\
\text { Постконтракцион- } \\
\text { ный период релакса- } \\
\text { ции (растяжения) }\end{array}$ \\
\hline \multirow[t]{2}{*}{ Земная кора } & $\begin{array}{l}\text { Приуроченность к } \\
\text { крупным блокам } \\
\text { повышенных зна- } \\
\text { чений гравитаци- } \\
\text { онного поля, к об- } \\
\text { ластям менее мощ- } \\
\text { ной земной коры }\end{array}$ & \multicolumn{2}{|c|}{$\begin{array}{l}\text { Приуроченность к крупным блокам пони- } \\
\text { женных значений гравитационного поля, } \\
\text { к областям наиболее мощной земной коры }\end{array}$} & $\begin{array}{l}\text { На периферии круп- } \\
\text { ных блоков повы- } \\
\text { шенных значений } \\
\text { гравитационного } \\
\text { поля, к областям } \\
\text { менее мощной } \\
\text { земной коры }\end{array}$ \\
\hline & \multicolumn{2}{|c|}{$\begin{array}{l}\text { Приуроченность к участкам коры с наи- } \\
\text { меньшей толщиной слабометаморфизо- } \\
\text { ванного осадочного слоя }\end{array}$} & \multicolumn{2}{|c|}{$\begin{array}{l}\text { На окраине участков коры увеличенной } \\
\text { мощности слабометаморфизованного оса- } \\
\text { дочного слоя }\end{array}$} \\
\hline
\end{tabular}


В региональном плане МЗКТ пространственно приурочены к крупным блокам пониженной плотности и массы (гравитационное поле), соответствующим областям наиболее мощной земной коры; невадийские и верхоянские месторождения приурочены к участкам коры с наименьшей толщиной слабометаморфизованного осадочного слоя, при этом такой закономерности в размещении китайских объектов не отмечается; невадийские и верхоянские месторождения пространственно контролируются относительно менее плотными и более нагретыми участками верхней мантии. Последнее не относится к китайским объектам, размещающимся на границе «прогретой» и «остывшей» области верхней мантии (табл. 2).

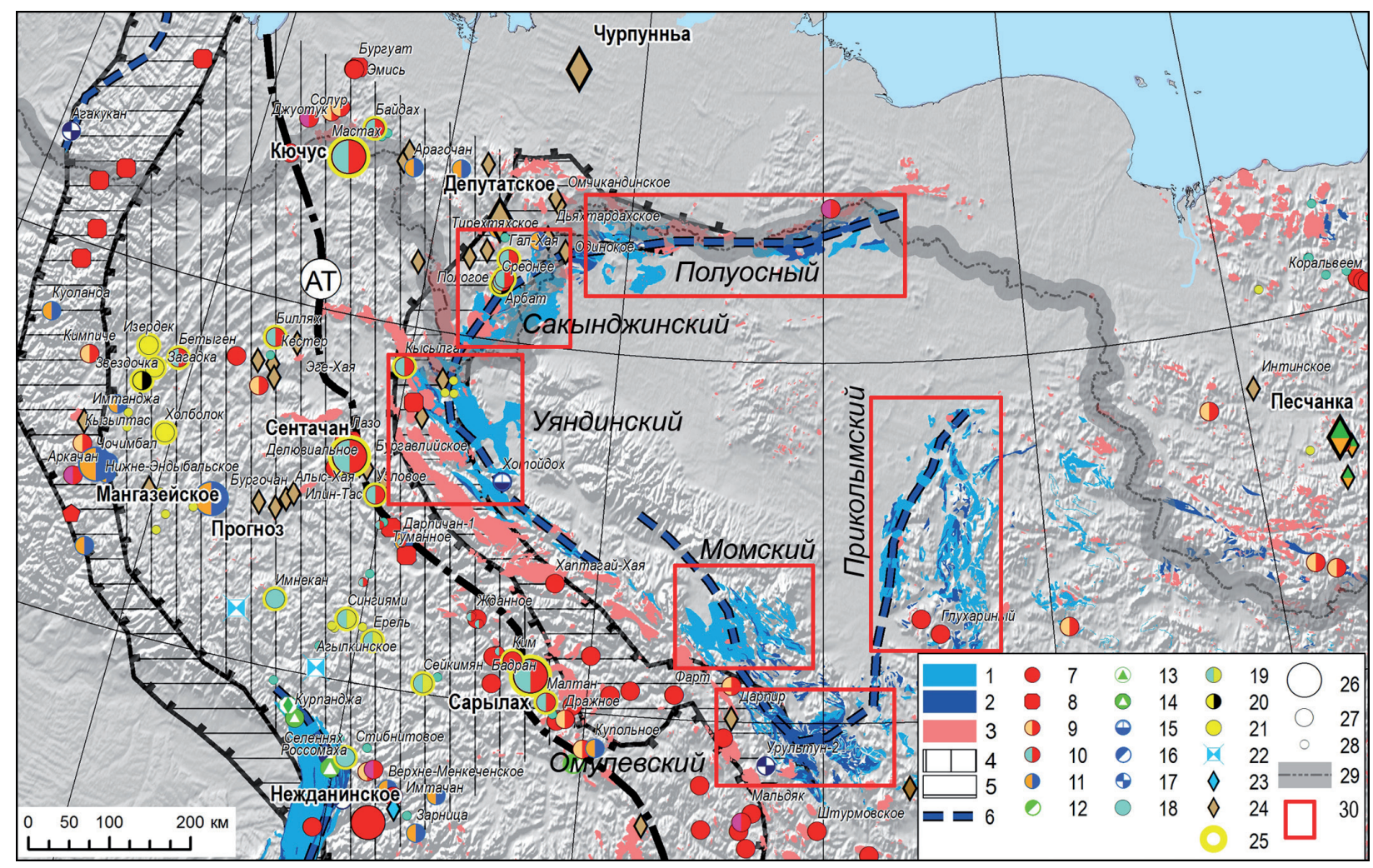

Рис. 3. Карбонатные формации, рифовые постройки, гранитоидные и диоритовые интрузивные образования Верхоянской провинции и позиция месторождений различных рудноформационных типов (с использованием материалов (Баранов, 2007; Константиновский, 2009; Кутыгин, 2018).

1-3 - формации: 1 - терригенно-карбонатная, 2 - карбонатная, 3 - гранитоиды; 4 - внешний и 5 - внутренний шельф; 6 - ось рифовых построек; 7-25 - рудные формации: 7 - Аu-кварцевая жильная, 8 - Au-сульфиднокварцевая, 9 - Au-Ag эпитермальная, 10 - Au-Sb, 11 - Ag-полиметаллическая, 12-13 - Сu-колчеданная в вулканогенных (12) и осадочных (13) породах, 14 - Сu песчаников, 15 - колчеданно-полиметаллическая в терригенных породах, 16 - Pb-Zn в вулканогенных породах, 17 - Pb-Zn стратиформная в карбонатных породах, 18 - кварц-антимонитовая, 19 - Sb-Hg эпитермальная, 20 - кварц-диккитовая эпитермальная, 21 - Hg аргиллизитовая, 22 - W-Мо скарновая, 23 - W-Мо грейзеновая, 24 - касситерит-силикатная, 25 - МЗКТ; масштабность месторождений: 26 - крупные, 27 - средние и мелкие, 28 - рудопроявления; 29 - арктическая зона РФ; 30 - перспективные на открытие МЗКТ рудные районы.

Fig. 3. Carbonate formations, reef structures, granitoid and diorite intrusives in the Verkhoyansk province and the position of deposits of various ore-formation types (using materials from [29-31]):1-3 - geological formations: 1 -terrigenous-carbonate, 2 - carbonate, 3 - granitoids; 4 - external shelf, 5 - internal shelf; 6 - axis of reef buildings; 7-25 - ore formations: 7 - Au-quartz vein, 8 - Au-sulphide-quartz, 9 - Au-Ag epithermal, 10 - Au-Sb, 11 - Agpolymetallic, 12-13 - Cu-pyrite in volcanogenic (12) and sedimentary (13) rocks, 14 - Cu sandstones, 15 - pyritepolymetallic in terrigenous rocks, $16-\mathrm{Pb}-\mathrm{Zn}$ in volcanic rocks, $17-\mathrm{Pb}-\mathrm{Zn}$ stratiform in carbonate rocks, 18 - quartzantimonite, 19 - Sb-Hg epithermal, 20 - quartz-dicquit epithermal, 21 - Hg mudstone, 22 - skarn W-Mo, 23 - greisen W-Mo, 24 - cassiterite-silicate, 25 - CTOD; scale of deposits: 26 - large, 27 - medium and small; 28 - occurrences; 29 - the Arctic zone of the Russian Federation; 30 - ore areas promising for the discovery of CTOD. 
Выполненный анализ геофизических моделей и геодинамических обстановок позволяет прогнозировать новые рудные районы с МЗКТ в Черско-Полоусненском покровно-складчатом поясе (Колымской петле) (рис. 3). Здесь силурийские и девонские рифовые системы закартированы в составе отложений карбонатных платформ (Баранов, 2007). Нами выделяются Яно-Индигирский, Момский, Омулевский, Приколымский и Нижне-Колымский сегменты (потенциальные рудные районы) Верхоянской провинции. Яно-Индигирский сегмент Черско-Полоусненского пояса включает Сакынджинский рудный район (рис. 3). Перечисленные выше потенциальные рудные районы, за исключением Момского по геофизическим и геологическим данным обладают большим сходством с Сакынджинским районом.

\section{Заключение}

В статье рассмотрены результаты изучения методами ГИС-анализа соотношения металлогении с геодинамическими обстановками в Арктической зоне Российской Федерации (АЗРФ). В основу исследований положена обновленная база данных по Арктике. По данным ГИС-анализа, в выступах докембрийского фундамента, террейнах пассивной и активной континентальных окраин размещено практически равное количество объектов (30 \%), а в коллизионной обстановке - 9 \% общего количества.

Показано, что в результате анализа геофизических моделей земной коры выявлено сходство геодинамических обстановок формирования невадийских и сакынджинских МЗКТ, что подтверждает высокие перспективы открытия крупных месторождений в этом арктическом районе Якутии. Новые рудные районы с МЗКТ прогнозируются на всем протяжении Черско-Полоусненского покровно-складчатого пояса (Колымской петли). Приведенные в статье материалы показывают высокие перспективы открытия на Северо-Востоке России новой металлогенической провинции месторождений золота Карлинского типа.

Работа выполнена при финансовой поддержке РФФИ (грант № 18-05-70001) «Изучение геологических и геодинамических обстановок формирования крупных месторождений стратегических металлов Арктической зоны России: выводы для прогнозирования и поисков новых месторождений».

\section{Литература}

1. Баранов В.В. Рифовые системы в силуре и раннем девоне Северо-Востока Азии // Отечественная геология. 2007. № 5. С. 43-50.

2. Волков А.В. Сидоров А.А. Геолого-генетическая модель месторождений золота Карлинского типа // Литосфера. 2016. № 6. С. 145-165.

3. Константиновский А.А. Осадочные формации Верхоянского пояса и обстановки их накопления // Литология и полезные ископаемые. 2009. № 1. С. 65-86.

4. Кутыгин Р.В. Основные черты стратиграфии и палеогеографии нижнедулгалах-ского регионального подъяруса пермской системы Якутии // Природные ресурсы Арктики и субарктики. 2018. Т.25. № 3. С. 5-21.

5. Парфенов Л.М. Континентальные окраины и островные дуги мезозоид северо-востока Азии. Новосибирск: Наука/ 1984. 192 с.

6. Поспелов И.И., Буянкин А.Г., Краснов А.Н. Геодинамические условия формирования и перспективы поисков золоторудных месторождений типа Карлин в северо-восточной Якутии // Вестник Госкомгеологии РС(Я). 2002. № 2. С. 14-18.

7. Bassin C., Laske G., Masters G. The Current Limits of Resolution for Surface Wave Tomography in North America // EOS Trans. AGU. 2000. V. 81. № 48. Fall Meet. Suppl., Abstract F897 (http://mahi.ucsd.edu/Gabi/rem.html).

8. Berger V.I., Mosier D.L., Bliss J.D., Moring B.C. Sediment-Hosted Gold Deposits of the World-Database and Grade and Tonnage Models. Open-File Report 2014-1074, June 2014, Virginia, Reston: U.S. Geological Survey. 2014. 46 p.

9. Bouman J. Ebbing J., Meekes S. et al. GOCE gravity gradient data for lithospheric model-ing. Int. J. Appl. Earth Obs. Geoinform, 2015. V. 35. P. 16-30.

10. Cammarano F., Guerri M. Global thermal models of the lithosphere// Geophys. J. Int. 2017. V. 210. P. 56-72.

11. Laske G., Masters G., Reif C. CRUST 2.0: A New Global Crustal Model at 2 Ч 2 Degrees. 2000. http://igppweb. ucsd.edu/ gabi/rem.html

12. Sampietro D., Reguzzoni M., Negretti N. The GEMMA crustal model: First validation and data distribution. ESASP. 2013. 722 p. 